\title{
EFEKTIFITAS TERAPI QUR'ANIC HEALING TERHADAP HALUSINASI PENDENGARAN PADA SKIZOFRENIA
}

\author{
Shella Febrita Puteri Utomo ${ }^{1}$, Popy Siti Aisyah ${ }^{2}$, Gilang Tresna Andika ${ }^{3}$ \\ 1,2 Universitas 'Aisyiyah Bandung; \\ ${ }^{3}$ Perawat Jiwa Rumah Sakit Jiwa Provinsi Jawa Barat \\ shella.utomo@yahoo.com
}

\begin{abstract}
ABSTRAK
Skizofrenia merupakan kerusakan pada proses pikir, ditandai oleh gejala negatif dan gejala positif. Prevalensi tertinggi masalah keperawatan pada gangguan jiwa yaitu halusinasi. Pendekatan spiritual sebaiknya diberikan untuk mengurangi gejala halusinasi. Terapi Qur'anic Healing digunakan kerena merupakan salah satu terapi modalitas dengan pendekatan spiritual yang memiliki manfaat dan dapat dilakukan di rumah sakit jiwa dalam memberikan asuhan dengan mendengarkan ayat suci Al-Qur'an. Tujuan penelitian ini untuk mengetahui efektifitas Terapi Qur'anic Healing terhadap halusinasi pada skizofrenia di Rumah Sakit Jiwa Provinsi Jawa Barat. Rancangan penelitian menggunakan Metode Quasi Eksperimen Pretest- Posttest with Control Design. Penelitian dilakukan terhadap 36 responden yaitu 18 kelompok kontrol dan 18 kelompok intervensi. Teknik pengambilan sampel dengan purposive sampling. Kriteria inklusi yaitu pasien skizofrenia dengan halusinasi, skor RUFA (Respon Umum Fungsi Adaptif) III, beragama Islam, di ruang perawatan hari ke-1, usia $>18$ tahun. Terapi dilakukan selama 6 hari dengan durasi 15 menit dengan Terapi Qur'anic Healing kemudian dilakukan posttes di akhir sesi. Instrumen yang digunakan yaitu AHRS (Auditory Hallucinations Rating Scale). Hasil penelitian terdapat perbedaan antara kelompok kontrol dan intervensi sebelum dan setelah pemberian terapi dengan nilai $p$-value $=0,000$. Dapat disimpulkan Terapi Qur'anic Healing efektif diberikan pada pasien halusinasi pada skizofrenia.
\end{abstract}

Kata Kunci: halusinasi, membaca Al-.Qur'an, terapi Qur'anic healing, skizofrenia, surat Ar- Rahman,

\section{THE EFFECTIVENESS OF QURANIC HEALING THERAPY ON HALLUCINATION AUDITORY IN PATIENTS WITH SCHIZOPHRENIA}

\section{ABSTRACT}

Schizophrenia is a mental disorder in which there was damage to the thought process, characterized by negative symptoms and positive symptoms. The highest prevalence of nursing problems in mental disorders is hallucinations. Intervention through a spiritual approach should give to reduce the symptoms of hallucinations. The Quranic healing therapy is a therapeutic modality with a spiritual system that has benefits and can be performed in a mental hospital as a nursing care provision by listening to the holy verses of the Koran. This study aimed to determine the effectiveness of Quranic healing therapy on hallucinations in patients with schizophrenia at the Cisarua Psychiatric Hospital, West Java Province. The research design used a quasi-experimental method with pre-test and post-test in two groups. The study was conducted on 36 respondents, with 18 respondents in the control and intervention groups. The sampling technique was purposive sampling. The inclusion criteria were schizophrenic patients with hallucinations, the score of RUFA III, Muslim, in the 1st day of care, age $>18$ years. The intervention carries out for six days with a duration of 15 minutes with Quranic healing. Then, a post-test was done at the end of the session. The instrument used was AHRS. The study results were differences 
between the control and intervention groups before and after giving therapy with a p-value of 0.000. Thus, it can conclude that Quranic healing therapy has effectively controlled hallucinations in schizophrenic patients.

Keywords: Ar-Rahman, hallucination, Quranic healing therapy, reading Al- Qur'an, schizophrenia

\section{PENDAHULUAN}

Skizofrenia merupakan kumpulan dari berbagai gejala pada gangguan jiwa yang terbagi menjadi gejala positif dan gejala negatif bersifat menetap dalam waktu sekitar 6 bulan (TandonR., Gaebel, W., Barch, D. M., Bustillo, J., Gur, R. E., Heckers, S., ... \& Van Os 2013). Skizofrenia adalah angguan jiwa psikotik dengan gejala positif, negatif, dan kognitif seperti hilangnya perasaan afektif atau respons emosional dan menarik diri dari hubungan antara pribadi normal. Sering kali diikuti dengan delusi (keyakinan yang salah) dan halusinasi adalah persepsi tanpa adanya rangsangan pancaindera (Zainuddin and Hashari 2019) .

Prevalensi kejadian skizofrenia terjadi peningkatan setiap tahun. Tahun 2013 tercatat angka skizofrenia sebanyak 2,1 juta jiwa dan meningkat di tahun 2018 menjadi 2,3 juta jiwa dari total jumlah penduduk dunia 7,5 miliar(WHO 2018). Indonesia juga mengalami peningkatan jumlah skizofrenia dilaporkan sekitar 1-2\% setiap tahunnya. Peningkatan jumlah gangguan jiwa di Jawa Barat sebanyak 63\% pada tahun 2018 dengan klasifikasi gangguan jiwa ringan hingga berat (Riskesdas 2018).

Hasil penelitian menemukan bahwa $70 \%$ pasien dengan skizofrenia di Jawa Barat ditemukan prevalensi tertinggi ada pada gangguan halusinasi pendengaran dan menjadi masalah yang paling umum terjadi (Riskesdas 2018). Halusinasi pendengaran merupakan bagian dari gejala positif, menggambarkan kondisi pasien mengalami kesalahan dalam mempersepsikan stimulus dari luar yang berhubungan dengan indra pendengaran. Kondisi tersebut disebabkan oleh banyak faktor diantaranya cemas dan depresi. Biasanya takut tidak diterima di lingkungan tertentu dan pengalaman traumatis. Gejala kecemasan tersendiri baik berat maupun sedang merupakan gangguan psikiatri (Costas, J., Carrera, N., Domínguez, E., Vilella, E., Martorell, L., Valero, J., ... \& Carracedo 2009; Stuart 2016; Suryani 2013).

Berdasarkan penelitian seseorang yang mengalami halusinasi pendengaran dapat merugikan diri sendiri, orang lain, dan lingkungan. Selain itu, halusinasi akan memengaruhi fungsifungsi sehingga menyebabkan masalah pada aspek biologis, sosial, dan spiritual. Keseriusan masalah disebabkan oleh isi halusinasi pendengaran yang dialami terkadang memberikan perintah untuk melakukan kekerasan pada orang lain, hingga melakukan percobaan bunuh diri (Dellazizzo et al. 2018; TandonR., Gaebel, W., Barch, D. M., Bustillo, J., Gur, R. E., Heckers, S., ... \& Van Os 2013). Di Indonesia isi halusinasi pendengaran kuat dikaitkan dengan pengaruh dari hal mistis seperti jin, setan dan mahluk halus lainnya (Suryani 2013).

Penatalaksaan yang dapat diberikan pada pasien halusinasi dengan pendekatan secara farmakologi dan nonfarmakologi (Prabowo 2014). Terapi farmakologi berupa penggunaan obat-obatan secara kimia yang tujuannya untuk mengontrol gejala psikosis dengan cepat karena melibatkan kerja neurontransmiter di otak. Penggunaan obat dalam jangka yang panjang dapat memberikan efek samping yang menyebabkan penderita skizofrenia menjadi malas minum obat. Efek samping diantaranya: adanya kekakuan pada lidah, penurunan motivasi, 
rasa tidak nyaman dalam tubuh, hipersaliva dan gejala parkinson. Terapi non farmakologi berupa terapi modalitas. Terapi modalitas merupakan terapi utama dalam keperawatan jiwa karena bertujuan untuk mengembangkan pola gaya atau kepribadian secara bertahap (Direja 2011). Terapi modalitas dibagi menjadi 7 jenis yaitu terapi kognisi, logoterapi, terapi keluarga, terapi lingkungan, terapi psikoreligius, terapi kelompok, dan program rencana pulang (Mardiati, Elita 2017).

Terapi yang dilakukan untuk mengontrol gejala halusinasi pendengaran sudah banyak dilakukan penelitian, diantaranya: metode EFT, Hypnoterapi, CBT, dan menunjukkan adanya penurunan yang signifikan pada gejala halusinasi. Menurut penelitian melihat karakter latar belakang budaya menggambarkan isi halusinasi di Indonesia berisikan suara-suara hal gaib/ mistis maka pendekatan secara spiritual dianggap lebih efektif mengatasi gejala halusinasi pendengaran (Gasril, Suryani, and Sasmita 2020; Suryani 2013). Terapi spiritual yaitu dengan Terapi Qur'anic Healing, yaitu terapi yang diberikan dengan mendengarkan lantunan ayat suci Al Qur,an dan memiliki niat serta keyakinan (Sumarni 2020). Terapi keagamaan (psikoreligius) terhadap penderita skizofrenia ternyata mempunyai manfaat (Rahmalia 2020). Hasil penelitian menunjukkan bahwa pasien yang diberikan terapi psikoreligius dapat mengurangi gejala klinis pada skizofrenia sehingga gejala positif lebih cepat terkontrol, lama perawatan (long stay hospitalization) lebih pendek, hendaya (impairment) lebih cepat tertatasi dan kemampuan beradaptasi lebih cepat (Rosyanti et al. 2018).

Qur'anic Healing dapat dilakukan dengan Metode Terapi Murottal yaitu terapi bacaan ayat-ayat Al-Qur'an selama beberapa menit atau bahkan beberapa jam sehingga memberikan dampak positif bagi tubuh seseorang (Rosyanti et al. 2018). Terapi Murottal dapat memberikan stimulan yang baik terhadap otak. Ketika seseorang mendengarkan ayat suci Al-Qur'an dapat memberikan respons rileks, tenang, dan rasa nyaman. Terapi dengan alunan bacaan Al-Qur'an dapat dijadikan alternatif terapi baru sebagai terapi relaksasi bahkan lebih baik dibandingkan dengan terapi audio lainnya karena stimulan Al-Qur'an dapat memunculkan gelombang delta sebesar 63,11\% (Abdurrachman \& Andhika, 2008) dalam (Zainuddin and Hashari 2019).

\section{METODOLOGI}

Penelitian ini menggunakan Metode Quasi Eksperimen Pretest- Posttest with Control Design. Pengukuran dilakukan di pagi hari setelah responden melakukan kegiatan makan, mandi, dan minum obat dengan mendengarkan lantunan ayat suci Al-Quran Surat Ar-Rahman sekitar 15 menit selama 6 hari. Terapi ini dilakukan di ruangan perawatan, terpisah dengan pasien lainnya dengan suasana yang tenang dan kondusif. Pengukuran dilakukan dua kali sebelum dilakukan dan setelah dilakukan terapi pada kelompok intervensi. Pengukuran kelompok kontrol juga dilakukan dua kali tanpa memberikan intervensi. Populasi dalam penelitian ini adalah pasien skizofrenia dengan halusinasi yang dirawat di ruang tenang sebanyak 36 respondene. Teknik sampling menggunakan purposive sampling dengan kriteria inklusi pasien skizofrenia dengan halusinasi, skor RUFA (Respon Umum Fungsi Adaptif) III, beragama Islam, di ruang perawatan hari ke 1, usia $>18$ tahun. Instrumen yang digunakan untuk mengukur halusinasi yaitu AHRS terdiri dari 11 item pertanyaan yang di kembangkan oleh Hoffman et al., 2003). Instrumen sudah dikatakan valid dengan nilai $r>0,3$ dan reliabel dibuktikan dengan nilai alpha $>0,60$.

Analisis data univariat dilakukan untuk 
melihat usia, jenis kelamin, pekerjaan dan pendidikan menggunakan distribusi frekuensi. Analisis bivariat untuk mengetahui perbedaan pada kelompok kontrol dan intervensi setelah diberikan perlakuan menggunakan Uji T-Test Independent dengan tingkat kepercayan 95\% ( $\alpha$ $\leq 0,05)$. Pelaksanaan penelitian memperhatikan prinsip dan etika penelitian, diantaranya: memberikan inform consent, menjaga dan menjamin kerahasiaan serta keamanan responden. Selain itu, prinsip dan etika dilakukan melalui persamaan persepsi pada enumerator pengambilan data. Terapi yang diberikan selama 6 hari dilakukan di pagi hari setelah klien makan dan minum obat, dengan durasi waktu 30 menit setiap sesi. Pengambilan data dilakukan saat awal dan akhir dari sesi yang dilakukan pada kelompok kontrol dan intervensi

\section{HASIL}

\section{Karakteristik Responden}

Tabel 1. Distribusi Frekuensi Karakteristik Responden $(n=36)$

\begin{tabular}{lcccc}
\hline & \multicolumn{4}{c}{ Kelompok } \\
\cline { 2 - 5 } & \multicolumn{2}{c}{ Intervensi $(\mathbf{n}=\mathbf{1 8})$} & $\mathbf{n}$ & $\mathbf{\%}$ \\
\cline { 2 - 5 } & $\mathbf{n}$ & $\mathbf{\%}$ & & \\
\hline Usia & & & 14 & 77,8 \\
Usia 18-45 tahun & 16 & 88,9 & $\mathbf{1 8}$ & 22,2 \\
Usia $>$ 45 tahun & 2 & 11,1 & $\mathbf{1 0 0}$ \\
\hline Total & $\mathbf{1 8}$ & $\mathbf{1 0 0}$ & $\mathbf{1 8})$ \\
\hline Jenis Kelamin & & & & \\
Laki-laki & 16 & 88,9 & 16 & 88,9 \\
Perempuan & 2 & 11,1 & 2 & 11,1 \\
\hline Total & $\mathbf{1 8}$ & $\mathbf{1 0 0}$ & $\mathbf{1 8}$ & $\mathbf{1 0 0}$ \\
\hline Pekerjaan & & & & \\
Bekerja & 9 & 50,0 & 4 & 22,2 \\
Tidak Bekerja & 9 & 50,0 & 14 & 77,8 \\
\hline Total & $\mathbf{1 8}$ & $\mathbf{1 0 0}$ & $\mathbf{1 8}$ & $\mathbf{1 0 0}$ \\
\hline Pendidikan & & & & \\
Tidak Sekolah & 3 & 16,7 & 6 & 33,3 \\
Pendidikan Dasar Menengah & 15 & 83,3 & 12 & 66,7 \\
\hline Total & $\mathbf{1 8}$ & $\mathbf{1 0 0}$ & $\mathbf{1 8}$ & $\mathbf{1 0 0}$ \\
\hline
\end{tabular}

Berdasarkan tabel 1 menunjukan bahwa usia terbanyak responden pada kelompok intervensi adalah 18-45 tahun sebanyak 16 orang $(88,9 \%)$ pada kelompok kontrol yaitu usia 18-45 tahun 14 orang $(77,8 \%)$. Jenis kelamin pada penelitian ini mayoritas laki-laki
16 responden $(88,9 \%)$ dan perempuan 2 responden $(11,1 \%)$ pada kedua kelompok. Status pekerjaan pada kelompok kontrol seimbang masing masing 9 orang (50\%) yang bekerja dan tidak bekerja. Sedangkan pada kelompok intervensi separuh responden tidak bekerja 
sebanyak 12 orang $(66,7 \%)$. Tingkat pendidikan pada kelompok kontrol di dominasi dengan tingkat pendidikan dasar sebanyak 15 orang $(83,3 \%)$ dan sebanyak 3 responden tidak sekolah. Sama halnya dengan kelompok Intervensi responden sebagian besar tingkat pendidikan hingga tingkat dasar sebanya 12 orang $(66,7 \%)$ dan 6 orang 33,3\%) tidak sekolah.

\section{Skor Halusinasi Klien Skizofrenia Pada Kelompok Kontrol $(n=18)$}

Tabel 2. Skor Halusinasi Pasien Skizofrenia di Rumah Sakit Jiwa Provinsi Jawa Barat pada Kelompok Kontrol (N=18)

\begin{tabular}{cccccccc}
\hline $\begin{array}{c}\text { Skor } \\
\text { Halusinasi }\end{array}$ & $\begin{array}{c}\text { Nilai } \\
\text { Minimum }\end{array}$ & $\begin{array}{c}\text { Nilai } \\
\text { Maksimum }\end{array}$ & Mean & SD & t hitung & t tabel & p-value \\
\hline Pre & 13 & 30 & 20,11 & 5,257 & 8,57 & 2,89 & 0,000 \\
Post & 9 & 25 & 15,72 & 4,738 & & \\
\hline
\end{tabular}

Pada tabel 2 di atas dapat dilihat bahwa skor halusinasi pada kelompok kontrol ketika pre test didapatkan nilai terendah 13 dan nilai tertinggi adalah 30 dengan rata-rata nilai adalah 20,11 dan setelah 6 hari dilakukan kembali pengukuran skor halusinasi didapatkan nilai terendah responden adalah 9 dan nilai tertinggi responden 25 dengan ratarata nilai 15,27 .

3. Skor Halusinasi Pasien Skizofrenia Diberikan Terapi Qur'anic Healing Pada Kelompok Intervensi $(\mathbf{n}=\mathbf{1 8})$

Tabel 3. Skor Halusinasi Pasien Skizofrenia Diberikan Terapi Quranic Healing di Rumah Sakit Jiwa Provinsi Jawa Barat pada Kelompok Kontrol $(\mathrm{N}=18)$

\begin{tabular}{cccccccc}
\hline $\begin{array}{c}\text { Skor } \\
\text { Halusinasi }\end{array}$ & $\begin{array}{c}\text { Nilai } \\
\text { Minimum }\end{array}$ & $\begin{array}{c}\text { Nilai } \\
\text { Maksimum }\end{array}$ & Mean & SD & t hitung & t tabel & p-value \\
\hline Pre & 12 & 30 & 21,50 & 5,659 & 11,436 & 2,89 & 0,000 \\
Post & 4 & 16 & 10,06 & 4,007 & & & \\
\hline
\end{tabular}

Sumber : Hasil Pengolahan Paired Sample Test, 2020

Pada tabel di atas dapat dilihat bahwa skor halusinasi pada kelompok Intervensi ketika pretest didapatkan nilai terendah 12 dan nilai tertinggi adalah 30 dengan rata-rata nilai adalah 21,50, setelah 6 hari diberikan Terapi Murottal dilakukan kembali pengukuran skor halusinasi didapatkan nilai terendah responden adalah 4 dan nilai tertinggi responden 16 dengan rata-rata nilai 10,06. Hasil nilai t hitung $>\mathrm{t}$ tabel maka terdapat perbedaan skor signifikan pada hasil AHRS

4. Pengaruh Terapi Qur'anic Healing Terhadap Skor Halusinasi pada Klien Skizofrenia (n=18)

Tabel 4. Pengaruh Terapi Qur'anic Healing pada Halusinasi Pendengaran Klien Skizofrenia (n=18)

\begin{tabular}{cccccc}
\hline Skor Halusinasi Post Test & Mean & SD & t hitung & t tabel & p-value \\
\hline Kelompok Intervensi & 10,06 & 4,007 & \multirow{2}{*}{3,87} & 2,73 & \multirow{2}{*}{0,000} \\
Kelompok Kontrol & 15,72 & 4,738 & & & \\
\hline
\end{tabular}


Berdasarkan tabel 4 dapat dilihat hasil uji independen sampel Uji $T$ Test menunjukkan nilai $p$-value 0,000 $(\mathrm{P}<0,005)$ yang memiliki arti terdapat pengaruh yang bermakna pada kelompok intervensi yang telah diberikan Terapi Qur'anic Healing selama 6 hari.

\section{PEMBAHASAN}

Penelitian ini dilakukan pada pasien gangguan jiwa dengan diagnosis keperawatan halusinasi pendengaran. Hasil penelitian menunjukkan sebelum dilakukan Qur'anic Healing Surat Ar- Rahman didapatkan nilai ratarata dari 18 responden di kelompok intervensi sebesar 21,50 dan pada kelompok kontrol skor 20,11. Berdasarkan hasil penelitian tahapan halusinasi pendengaran kedua kelompok responden berada pada tahapan condeming. Tahapan ini menunjukkan gejala pengalaman sensori sering datang dan terkadang mengalami kesulitan membedakan apakah suara itu nyata atau halusinasi, responden merasa tidak mampu mengontrolnya, dan merasa aneh, takut dan juga bingung dengan pengalaman yang di rasakan.

Berdasarkan hasil wawancara meggunakan kuesioner AHRS sebelum dilakukan Terapi Qur'anic Healing hampir 90\% responden sering mendengar suara di setiap saat, dengan durasi waktu yang bervariasi bahkan hingga berjam-jam. Sumber suara bermacam-macam dan sangat kuat sehingga responden bingung membedakan suara yang nyata dan tidak. Keyakinan sumber suara juga sangat beragam hal ini menurut penelitian sangat di pengaruhi oleh latar belakang budaya (Wahid and Nashori 2021).

Halusinasi adalah terganggunya persepsi sensori seseorang tanpa adanya stimulus. Dalam penelitian ini halusinasi yang menjadi fokus merupakan halusinasi pendengaran. Berdasarkan kajian literatur ditemukan kejadian tertinggi yaitu halusinasi lebih dari 90\% klien dengan Skizofrenia mengalami halusinasi pendengaran (Nurya 2019). Menurut Stuart, 2016 gejala halusinasi ditunjukkan dengan perilaku responden selalu mengatakan mendengar suarasuara yang tidak didengar oleh orang lain, klin juga tampak tidak konsentrasi, tatapan tidak fokus, sering menutup telinga (Nurya 2019).

Sebagai suatu hal yang biasa. Hal ini sejalan dengan teori Stuart yang mengatakan bahwa tahapan condemning masih menunjukkan gejala pengalaman sensori klien menjadi sering datang dan sering mengalami bias. Klien mulai merasa tidak mampu lagi mengontrolnya dan mulai berupaya menjaga jarak antara dirinya dengan objek yang dipersepsikan (Stuart 2016) sehingga pada tahapan ini responden cukup sulit jika diberikan intervensi dikarenakan halusinasi masih cukup mendominasi responden.

\section{Skor Halusinasi Setelah Diberikan Qur'anic Hiling Surat Ar-Rahman pada Kelompok Intervensi}

Hasil penelitian yang telah dilakukan dengan memberiakan terapi quranic healing surat Ar - Rahman pada kelompok intervensi sebanyak 18 orang dengan skizofrenia diagnosa keperawatan halusinasi pendengaran. Intervensi dilakukan selama 6 hari dengan durasi waktu selama 30 menit setiap sesi di pagi hari atau setelah responden makan dan minum obat. Hasil penelitian menunjukan terdapat penurunan skor halusinasi. Sebelum dilakukan intervensi ratarata skor halusinasi berada pada 21,50 setelah diberikan intervensi terjadi penurunan skor menjadi 10,06 .

Qur'anic Healing merupakan terapi nonfarmakologi yang dapat diberikan pada pasien gangguan jiwa. Terapi ini bagian dari terapi modalitas yaitu psikoreligius (Gasril, Suryani, and Sasmita 2020). Berdasarkan kajian literatur ditemukan psikoreligius efektif dapat 
menurunkan gejala positif pada gangguan jiwa skizofrenia (Devina 2020). Qur'anic Healing dengan mendengarkan Murottal Surat ArRahman dapat memberikan dampak positif bagi tubuh dan menumbuhakan rasa ketenangan dan nyaman. Pada pasien yang mengalami halusinasi, terjadi ketidakseimbangan hormon dopamin sehingga timbulnya persepsi yang salah meskipun tidak ada stimulus dari luar (Zainuddin and Hashari 2019).

Berdarkan hasil penelitian Terapi Qur'anic healing dengan mendengarkan Murotal Surat Ar-Rahman dapat merangsang otak untuk menurunkan hormon stres, dan mengaktifkan pengeluaran hormon endrofin alami yaitu serotonin sehingga dampak yang di rasakan oleh tubuh yaitu rasa ketenangan, lebih fokus, hilangnya perasaan cemas dan tegang (Al-Kaheel 2013). Individu yang teratur mendengarkan ayat suci al- quran dapat menurunkan tingkat depresi (Ahmad, 2010). Quranic healing terbukti efektif dapat menurunkan frekuensi gejala halusinasi pada pasien skizofrenia. Membaca dan mendengarkan lantunan ayat suci Al-Qur'an menstabilkan getaran neuron dan menurunkan hormon kortisol sehingga muncul rasa ketenangan. Hal ini dapat memberikan efek pada responden sehingga mampu mengontrol halusinasinya (Wahid and Nashori 2021).

Al-Qur'an terbukti dapat meningkatkan kondisi mental seseorang dan menjadi penyembuh penyakit. Hal ini dibuktikan dalam surat Yunus ayat 52 yang artinya "Wahai manusia, sungguh telah datang kepadamu pelajaran Al-Qur'an dari tuhanmu. Penyembuh bagi penyakit yang ada dalam dada dan petunjuk serta rahmat bagi orang yang beriman". Mendengarkan Murottal Al-Qur'an akan menimbulkan suatu medan gelombang yang akan memengaruhi gelombang otak manusia. Dengan menggunakan alat electroencephalograph (EEG), terlihat reaksi otak berupa perubahan gelombang otak dari frekuensi beta (di atas $12 \mathrm{~Hz}$ sampai dengan $20 \mathrm{~Hz}$ ) menjadi frekuensi alfa ( $8 \mathrm{~Hz}$ sampai dengan 12 $\mathrm{Hz}$ ) yang membuat kondisi tubuh dalam keadaan rileks (Wahid and Nashori 2021). Pada tahap selanjutnya akan terjadi peningkatan frekuensi gelombang delta $(0,5 \mathrm{~Hz}$ sampai dengan $4 \mathrm{~Hz})$ yang akan membuat tingkat relaksasi lebih dalam dan penurunan depresi yang signifikan. Semua reaksi pada otak yang dipengaruhi oleh medan gelombang tersebut akan meningkatkan berbagai neurotransmitter seperti serotonin dan dopamine sehingga terjadi perubahan perilaku menjadi lebih tenang dan rileks sehingga pasien dengan halusinasi bisa mengontrol dan membedakan suara yang tidak nyata dan nyata (Zainuddin and Hashari 2019).

\section{Perbandingan Skor Halusinasi Sebelum dan Setelah Terapi Murrotal Surat Ar-Rahman pada Kelompok Kotrol Dan Kelompok Intervensi}

Berdasarkan hasil penelitian sebelum diberikan Terapi Murotal Al- Qur'an pada pasien skizofrenia dengan halusinasi pendengaran responden pada kelompok intervensi menunjukan gejala terkadang berbicara sendiri, seperti sedang berkomunikasi dengan orang lain secara berbisikbisik, dan rerata skor yang dihasilkan adalah 21,5. Berdasarkan gejala dan skor berada pada fase condemning. Apabila dinilai menggunakan skor rufa responden pada kelompok intervensi berada pada kondisi RUFA 3 (21-30).

Setelah diberikan terapi kelompok intervensi menunjukkan terjadi penurunan rerata skor halusinasi pendengaran menjadi 10,6. Gejala yang ditunjukan yaitu responden lebih tenang, tidak tampak berbicara sendiri, konsentrasi lebih fokus. Berbeda dengan kelompok kontrol yang tidak diberikan terapi selama 6 kali dalam 6 hari, rerata skor halusinasi pada awal pengkajian adalah 20,11 dan setelah 6 hari dikaji kembali rerata skor halusinasi pendegaran menjadi 15,72 
yaitu terjadi penurunan skor halusinasi, namun tidak sebesar kelompok intervensi, dengan nilai p- value pada Uji Independent Sample Test didapatkan $0,000(<0,05)$. Hal ini terbukti bahwa terdapat perbedaan yang signifikan terhadap skor hausinasi pendengaran pada pasien skizofrenia dengan pemberian Terapi Murotal Surat ArRahman.

Mendengarkan Murotal Surat Ar-Rahman pada seorang individu dapat memberikan rangsangan otak karena terdapat gelombang suara yang mengalir. Menurut penelitian apabila dilihat menggunakan suatu alat EEG electrochephalograph akan terlihat bagaimana perubahan reaksi otak berupa frekuensi beta, yaitu suatu gelombang yang melebihi dari 12 - $20 \mathrm{~Hz}$ menjadi alfa $8-12 \mathrm{~Hz}$. Perubahan gelombang inilah yang dapat memberikan rasa nyaman, rileks dan tenang akibat dari pengeluaran horon penurun stres. Apabila diberikan dalam waktu yang lama, dan teratur maka perubahan gelombang akan mencapai geombang delta yaitu 0,5- $4 \mathrm{HZ}$ kondisi ini akan memberikan tingkat rileks yang lebih dalam sehingga terjadi perubahan skor halusinasi dan penurunan rasa depresi. Gelombang delta merupakan suatu gelombang utama yang berperan untuk mengatur aktivitas istrahat individu dan dapat mempengaruhi perubahan perilaku sehingga terjadi penurunan skor halusinasi.

\section{SIMPULAN DAN SARAN}

Skizofrenia merupakan gangguan jiwa yang ditandai munculnya gejala negatif dan gejala positif diantaranya dengan masalah halusinasi. Setelah diberikan Terapi Qur'anic Healing pada kelompok intervensi terdapat perbedaan sebelum dan setelah terapi dan mendapatkan nilai $p$-value 0,000. Dapat disimpulkan quranic healing efektif dapat menurunkan gejala halusinasi pada skizofrenia. Oleh karena itu, saran pada penelitian ini perawat jiwa dapat mengaplikasikan Terapi
Quranic Healing dengan mendengarkan murrotal pada gejala halusinasi. Pada peneliti selanjutnya dapat dilakukan pengamatan jangka panjang tentang efektifitas Terapi Quranic Healing dan bagi rumah sakit jiwa dapat menjadi pertimbangan untuk melakukan kegiatan mendengarkan Alquran untuk menurunkan gejala halusinasi pendengaran pasien dengan skizofrenia

\section{DAFTAR PUSTAKA}

Al-Kaheel, Abdel Daem. 2013. Pengobatan Qur'ani, Manjurnya Berobat Dengan AlQur'an. 2nd ed. Jakarta: Amzah.

Costas, J., Carrera, N., Domínguez, E., Vilella, E., Martorell, L., Valero, J., ... \& Carracedo, Á. 2009. "A Common Haplotype of DRD3 Affected by Recent Positive Selection Is Associated with Protection from Schizophrenia." 124(6): 607-13.

Dellazizzo, Laura et al. 2018. “Avatar Therapy for Persistent Auditory Verbal Hallucinations in an Ultra-Resistant Schizophrenia Patient: A Case Report." Frontiers in Psychiatry 9(APR).

Devina, Yeni. 2020. “Terapi Al- Quran Dalam Mengontrol Halusinasi Pada Pasien Skizofrenia." jurnal kesehatan 11(111114).

Direja, Ade Herman Surya. 2011. Buku Ajar Asuhan Keperawatan Jiwa. 1st ed. Yogyakarta: Nuha Medika.

Gasril, Pratiwi, Suryani Suryani, and Heppi Sasmita. 2020. "Pengaruh Terapi Psikoreligious: Dzikir Dalam Mengontrol Halusinasi Pendengaran Pada Pasien Skizofrenia Yang Muslim Di Rumah Sakit Jiwa Tampan Provinsi Riau." Jurnal Ilmiah Universitas Batanghari Jambi 20(3): 821.

Mardiati, Elita, Sabrian. 2017. "Pengaruh Terapi Psikoreligius : Membaca Al Fatihahterhadap Skor Stuart 
2012 ) Mendefinisikan Halusinasi Sebagai Distorsipersepsipalsu Yang Terjadipadarespon Neurobiology Yang Maladaptive . Lanjutan Oleh Perawat Jiwa Untuk Melaksanakan Terapi Yang Diguna." Jurnal Kesehatan 8(1).

Nurya, Kumala. 2019. “Jenis Halusinasi Yang Dominan Pada Klien Dengan Skizofrenia Hebefrenik Di Rumah Sakit Jiwa Menur Surabaya 1." Jurnal Kesehatan XII(1): 7-11.

Prabowo, Eko. 2014. Buku Ajar Keperawatan Jiwa. Yogyakarta: Nuha Medika.

Rahmalia, Indah Dewanti. 2020. "Efektivitas Terapi Mendengarkan Murottal AlQur'an Surat Ar-Rahman Untuk Meningkatkan Ketenangan Jiwa Pada Informal Caregiver Skizofrenia.” Jurnal Universtas Islam Indonesia.

Riskesdas. 2018. "Laporan Nasional 2018."

Rosyanti, Lilin, Veny Hadju, Indriono Hadi, and Syahrianti Syahrianti. 2018. "Pendekatan Terapi Spiritual Al-Quranic Pada Pasien Skizoprenia Tinjauan Sistematis." Health Information: Jurnal Penelitian 10(1): 39-52. https://myjurnal.poltekkes-kdi. ac.id/index.php/HIJP/article/view/103.

Stuart, GW. 2016. Prinsip Dan Praktek Keperawatan Jiwa Stuart. elsivier.
Sumarni, Sumarni. 2020. "Proses Penyembuhan Gejala Kejiwaan Berbasis Islamic Intervention Of Psychology." NALAR: Jurnal Peradaban dan Pemikiran Islam 3(2): 134-47.

Suryani, Suryani. 2013. "Pengalaman Penderita Skizofrenia Tentang Proses Terjadinya Halusinasi Suryani." Jurnal Keperawatan Padjadjaran v1(n1): 1-9.

TandonR., Gaebel, W., Barch, D. M., Bustillo, J., Gur, R. E., Heckers, S., ... \& Van Os, J. 2013. "Definition and Description of Schizophrenia in the DSM-5." Schizophrenia research 150(1): 3-10.

Wahid, Abdi Winarni, and Fuad Nashori. 2021. "The Effectiveness of Al-Quran Surah Ar-Rahman Murottal Listening Therapy for Improving Positive Emotions on Informal Caregivers of Schizophrenia." Proceedings of the International Conference on Psychological Studies (ICPSYCHE 2020) 530(Icpsyche 2020): 264-71.

WHO. 2018. "The World Health Report: 2018: Mental Health."

Zainuddin, Ricky, and Rahmiyanti Hashari. 2019. "Efektifitas Murotal Terapi Terhadap Kemandirian Mengontrol Halusinasi Pendengaran." jurnal keperawatan Muhammadiyah. 
